\title{
Hubungan Gangguan Neurobehavior dengan Paparan Pestisida pada Pekerja Perkebunan Teh PT X Kabupaten Cianjur
}

\author{
Zahra Salsabila Firdaus*, Ismet Muchtar Nur \\ Prodi Pendidikan Dokter, Fakultas Kedokteran, Universitas Islam Bandung, \\ Indonesia.
}

*zsalsabilafirdaus99@gmail.com, ismet.mnur@yahoo.com

\begin{abstract}
Background: The use of pesticides in plantations or agriculture includes insecticides, herbicides, fungicides, rosenticides, and fumigants are chemicals from several groups, namely organochlorines, organophosphates, carbamates, and pyrethroids. Pesticides that are widely used in agriculture and plantations are the organophosphate group because this group is easier to decompose in nature. Besides being able to increase agricultural product yields, pesticides can also have a negative impact on workers in plantations due to exposure to pesticides, including nervous system disorders in the form of neurobehavioral disorders, which are harmful changes or functional disorders of the nerves, both the central nervous system and peripheral nervous system with symptoms / signs - a sign of changes in memory, attention, mood, disorientation, thinking irregularities, as well as changes in somatic, sensory, and cognitive function as neurotoxic effects due to the use of neurotoxicants. Aim: Research on workers in tea plantations aims to determine the relationship between neurobehavioral disorders in spraying workers (who use pesticides) in tea plantations. Method: This study used an observational analytic method which aims to reveal the correlative relationship between variables using a cross sectional group design approach and using a total sampling technique. The population and research sample amounted to 30. This study used a questionnaire The German Q18 Quesionnaire. The independent variable in this study is pesticides and the dependent variable in this study is neurobehavioral disorders. Univariate data analysis using frequency distribution and bivariate using chi-square. Result : The results showed that there was a relationship between the neurubehavioral disorders experienced by workers and the length of exposure to pesticides seen from their working period. The number of respondents who experienced neurobehavior disorders was 18 people $(60.0 \%)$ had negative neurobehavioral disorders and as many as 12 people $(40.0 \%)$ had positive neurobehavioral disorders. Chi-Square test results obtained $\mathrm{p}$ value $=0.011<\alpha$ $(0.05)$, which means that there is a significant relationship / correlation between neurobehavioral disorders and exposure to pesticides in tea plantation workers of PT. X Cianjur Regency. Conclusion: in this study, there are neurobehavior disorders in plantation wprkers who use pesticides.
\end{abstract}

Keywords: Neurobehavior Disorders, Pesticide Exposure, Tea Plantation Workers.

Abstrak. Latar Belakang: Penggunaan pestisida dalam perkebunan atau pertanian meliputi insektisida, herbisida, fungisida, rosentisida, dan fumigan merupakan bahan kimia dari beberapa golongan yaitu organoklorin, organofosfat, karbamat, dan piretroid. Pestisida yang banyak digunakan di bidang pertanian dan perkebunan adalah golongan organofosfat karena golongan ini lebih mudah terurai di alam. Selain dapat meningkatkan hasil produk pertanian, pestisida juga dapat memberikan dampak negatif bagi pekerja di perkebunan akibat paparan pestisida, antara lain gangguan sistem saraf berupa gangguan neurobehavioral, yaitu perubahan berbahaya atau gangguan fungsional saraf, baik sistem saraf pusat dan sistem saraf tepi dengan gejala/tanda - tanda perubahan daya ingat, perhatian, mood, disorientasi, ketidakteraturan berpikir, serta perubahan fungsi somatik, sensorik, dan kognitif sebagai efek neurotoksik akibat penggunaan neurotoksikan. Tujuan: Penelitian pada pekerja di perkebunan teh bertujuan untuk mengetahui hubungan gangguan neurobehavioral pada pekerja penyemprotan (pengguna pestisida) di perkebunan teh. Metode: Penelitian ini menggunakan metode observasional analitik yang bertujuan untuk mengungkap hubungan korelasional antar variabel dengan menggunakan pendekatan cross sectional group design dan menggunakan teknik total sampling. Populasi dan sampel penelitian berjumlah 30. Penelitian ini menggunakan kuesioner The German Q18 Quesionnaire. Variabel bebas dalam penelitian ini adalah pestisida dan variabel terikat dalam penelitian ini adalah gangguan neurobehavioral. Analisis data univariat menggunakan distribusi frekuensi dan bivariat menggunakan chi-square. Hasil : Hasil penelitian menunjukkan bahwa ada hubungan antara gangguan neurobehavioral yang dialami pekerja dengan lama paparan pestisida dilihat dari masa kerjanya. Jumlah responden yang mengalami gangguan neurobehavior sebanyak 18 orang $(60,0 \%)$ mengalami gangguan neurobehavior negatif dan sebanyak 12 orang $(40,0 \%)$ mengalami gangguan neurobehavior positif. Hasil uji Chi-Square diperoleh $\mathrm{p}$ value $=0,011<(0,05)$, yang berarti terdapat hubungan/korelasi yang signifikan antara gangguan neurobehavioral dengan paparan pestisida pada pekerja perkebunan teh PT. X Kabupaten Cianjur. Kesimpulan: pada penelitian ini terdapat gangguan neurobehavior pada pekerja perkebunan yang menggunakan pestisida..

Kata Kunci: Gangguan Neurobehavior, Paparan Pestisida, Pekerja Perkebunan Teh. 


\section{A. Pendahuluan}

Penggunaan pestisida pada perkebunan ataupun pertanian terdiri dari berbagai jenis diantaranya insektisida, herbisida, fungisida, rosentisida, dan fumigan. Insektisida terdiri dari beberapa golongan yaitu organoklorin, organofosfat, karbamat, dan piretroid. Pestisida yang banyak direkomendasikan di bidang pertanian adalah golongan organofosfat karena golongan ini lebih mudah terurai di alam. Pajanan pestisida pada manusia dapat melalui beberapa cara, yaitu inhalasi (dihirup dari udara dan masuk ke sistem pernafasan), ingesti (ditelan dari makanan yang dikonsumsi), dan kontak kulit.

Data World Health Organization (WHO) dan United Nations Environment Programme (UNEP) memperkirakan ada 1,5 juta kasus keracunan pestisida terjadi pada pekerja disektor perkebunan. Sebagian besar kasus keracunan pestisida tersebut dinegara berkembang.

Selain dapat meningkatkan hasil produk pertanian, pestisida mempunyai dampak negatif seperti berkurangnya keanekaragaman hayati, pestisida berspektrum luas dapat membunuh hama sasaran, parasitoid, predator, hiperparasit serta makhluk bukan sasaran seperti lebah, serangga penyerbuk, cacing dan serangga bangkai. Satu sisi penggunaan pestisida memberikan keuntungan bagi produktivitas pertanian, di sisi lain pestisida memberikan dampak buruk terhadap kesehatan masyarakat dan lingkungan karena penggunaan yang sering tidak terkendali dan berlebihan atau tidak tepat. Penelitian yang dilakukan oleh Fadilah (2013) menyebutkan petani penyemprot tanaman sayur dengan pestisida yang mengalami efek neurobehavior sebanyak $60.6 \%$ responden. Dimana efek neurobehavioral terjadi pada uji digit span yaitu pada $21.2 \%$ responden, digit symbol pada $25.8 \%$, pursuit aiming sebanyak $24.2 \%$, dan trial making sebanyak $24.2 \%$ responden.

Penggunaan pestisida pada pertanian dapat menimbulkan efek neurobehavior didefinisikan sebagai perubahan yang merugikan atau gangguan secara fungsional pada saraf baik sistem saraf pusat maupun sistem saraf tepi yang diakibatkan oleh paparan suatu bahan kimia, agen fisik maupun biologis yang lebih dikenal dengan zat neurotoksik atau neurotoksikan. Gangguan ini mengakibatkan perubahan pada memori, attention, mood, disorientasi, penyimpangan berfikir, serta perubahan somatik, sensorik, dan fungsi kognitif. Lamanya pajanan pestisida sering menyebabkan gangguan kognitif, gangguan memori hingga gangguan mood yang dipengaruhi oleh usia.

Beberapa penelitian juga menunjukkan bahwa pajanan pestisida kronis memiliki berbagai efek neurobehavior, termasuk timbulnya penyakit alzheimer dan demensia. Dalam sebuah penelitian terhadap 614 pekerja pertanian di Perancis, kelompok dengan pajanan pestisida yang lebih besar memiliki skor lebih rendah pada tes fungsi kognitif daripada kelompok tanpa paparan. Namun, bukti epidemiologis pada efek neurobehavior dari paparan pestisida kronis masih terbatas. Peningkatan yang signifikan dalam jumlah orang dengan penurunan neurobehavior di antara mereka yang berusia lebih tinggi dan kelompok tingkat pendidikan yang lebih rendah. Semakin besar tingkat paparan pestisida, semakin tinggi gangguan terjadi neurobehavioral.

\section{B. Metodologi}

Penelitian ini menggunakan metode analitik observasional yang bertujuan mengungkapkan hubungan korelatif antar variabel dengan menggunakan pendekatan cross sectional group design, yaitu rancangan penelitian yang pengukuran atau pengamatannya dilakukan secara simultan pada satu saat atau sekali waktu. Pengambilan data diawali dengan responden yang memiliki riwayat penyakit hipertiroidisme, stroke, anemia (Hb rendah), malnutrisi, asma, PPOK (Penyakit pulmonari obstruktif kronis), tuberkulosis, vertigo dan penyakit jantung sebelum 
terpapar pestisida. Setelah data terkumpul, selanjutnya dilakukan pengolahan data untuk selanjutnya dilakukan penyajian data dalam bentuk deskriptif.

\section{Pembahasan dan Diskusi}

\section{Hasil Penelitian}

Penelitian ini dilakukan di wilayah perkebunan teh PT. X Kabupaten Cianjur pada bulan Februari 2020, dengan subjek penelitian adalah pekerja bagian penyemprotan pada perkebunan teh PT.X Kabupaten Cianjur. Jumlah pekerja yang diteliti ada sebanyak 30 orang pekerja, dari 30 orang pekerja yang memenuhi persyaratan kriteria inklusi untuk diteliti.

Tabel 1. Gangguan Neurobihavioral Pada Pekerja Yang Menggunakan Pestisida

\begin{tabular}{lccc} 
& Kategori & Jumlah & \% \\
\hline Positif & 12 & 40,0 \\
Negatif & 18 & 60,0 \\
\hline Total & 30 & 100 \\
\hline
\end{tabular}

Dari 30 responden yang diteliti yaitu sebanyak 18 orang $(60,0 \%)$ memiliki gangguan neurobehavioral yang negative dan sebanyak 12 orang $(40,0 \%)$ memiliki gangguan neurobehavioral yang positif.

Tabel 2. Paparan Pestisida Pada Pekerja Perkebunan

\begin{tabular}{lccc}
\hline & Kategori & Jumlah & \% \\
\hline Lama paparan & & \\
$>1-5$ tahun & 16 & 53,3 \\
$>5$ tahun & 14 & 46,7 \\
\hline Total & 30 & 100 \\
\hline
\end{tabular}

Table 4.2 menunjukkan bahwa sebagian besar responden yang diteliti yaitu sebanyak 16 orang $(53,3 \%)$ mengalami paparan pestisida yang masa kerja $>1-5$ tahun dan sebanyak 14 orang $(46,7 \%)$ mengalami paparan pestisida yang masa kerjanya $>5$ tahun.

Tabel 3. Hubungan Gangguan Neurobehavior Dengan Paparan Pestisida Pada Pekeja Perkebunan teh PT. X Kabupaten Cianjur

\begin{tabular}{lcccc}
\hline \multirow{2}{*}{ Gangguan Neurobehavioral } & \multicolumn{2}{c}{ Paparan Pestisida } & \multirow{2}{*}{ Total } & \multirow{2}{*}{ Nila $\mathrm{p}$} \\
\cline { 2 - 3 } Positif & $>1-5$ tahun & $>5$ tahun & & \\
Negatif & 3 & 9 & 12 & \\
\cline { 1 - 4 } Total & 13 & 5 & 18 & 0,011 \\
\hline
\end{tabular}

Table 4.3 diatas diperoleh nilai $\mathrm{p}$ value $=0,011<\alpha(0,05)$ yang berarti bahwa terdapat hubungan/korelasi yang signifikan antara gangguan neurobehavioral dengan paparan pestisida pada pekerja perkebunan teh PT. X Kabupaten Cianjur. 


\section{Pembahasan}

1. Gangguan Neurobihavioral Pada Pekerja Yang Menggunakan Pestisida

Pada penelitian yang dilakukan pada pekerja perkebunan teh PT.X Kabupaten Cianjur dengan jumlah 30 orang pekerja laki-laki didapatkan hasil menunjukkan bahwa yang memiliki Gangguan Neurobihavior Pada Pekerja Yang Menggunakan Pestisida yaitu sebanyak 18 orang $(60,0 \%)$ memiliki gangguan neurobehavioral yang negative dan sebanyak 12 orang $(40,0 \%)$ memiliki gangguan neurobehavioral yang positif. Dengan kriteria jawaban ya dan tidak didapatkan dari hasil kuesioner Q18 yang diberikan kepada pekerja. Dikategorikan positif jika jawaban iya $>5$ dan negatif jika jawaban nya $<5$ untuk pekerja laki-laki.

Hasil penelitian ini sesuai dengan yang dilakukan oleh Zainul Fadilah dengan judul efek neurobehavioral dan faktor determinannya pada petani penyemprot tanaman yang menunjukan bahwa gambaran efek neurobehavioral pada petani penyemprot tanaman sayur dengan pestisida di Desa Perbawati Kabupaten Sukabumi Tahun 2013 yaitu sebanyak $60.6 \%$ responden mengalami performa neurobehavioral buruk (tidak normal). Efek neurobehavioral terjadi pada uji digit span yaitu $21.2 \%$ respoden, digit symbol $25.8 \%$ responden, pursuit aiming sebanyak $24.2 \%$, dan trial making sebanyak $24.2 \%$ reponden. Dengan begitu adanya efek neurobehavioral pada petani penyemprot sayuran dengan pestisida.

2. Paparan pstisida pada pekerja perkebunan

Hasil penelitian yang dilakukan terhadap 30 orang pekerja perkebunan menunjukkan bahwa sebagian besar responden yang diteliti yaitu sebanyak 16 orang $(53,3 \%)$ mengalami paparan pestisida yang akut dan sebanyak 14 orang $(46,7 \%)$ mengalami paparan pestisida yang kronis. kejadian yang lebih banyak dimungkinkan karena waktu paparan.

Hasil penelitian ini sesuai dengan yang dilakukan oleh fitriani antika damayanti dan fitria saftarina dengan judul ''Efek Neurobehavioral akibat Paparan Kronik Organofosfat pada Petani" "menyatakan bahwa paparan organofosfat dalam jangka waktu yang lama dapat menyebabkan efek neurobehavioral pada petani. ${ }^{29}$

Pada penelitian lain juga, menyatakan bahwa masa paparan pestisida pada pekerja perkebunan merupakan faktor resiko terjadinya gangguan neurobihavior pada pekerja pekerbunan.

Hasil penelitian ini juga sesuai dengan penelitian dari Ni Luh Diarasandhi Semedi Putri dengan judul Paparan Organofosfat kronik sebagai faktor risiko gangguan kognitif berdasarkan kadar phosphorylated tau serum dengan dipatkan hasil nya bahwa subjek dengan lama paparan pestisida $>10$ tahun memiliki kadar protein $\mathrm{p}$-tau serum yang lebih tinggi dibandingkan dengan yang $<10$ tahun secara bermakna $(p=0,003)$. Dengan begitu didapatkan adanya kesimpulan bahwa dalam penelitian tersebut terdapat adanya paparan kronik pestisida jenis organofosfat meningkatkan risiko terjadinya gangguan fungsi kognitif secara parsial.

Hasil penelitian Devi Purnama Sari mendukung dengan kesimpulan kejadian MCI ditemukan pada 63 petani $(63,0 \%)$, masa kerja $>5$ ditemukan pada 71 petani $(71,0 \%)$, frekuensi penyemprotan $>2$ /minggu ditemukan pada 64 petani $(64,0 \%)$, penggunaan APD $(\mathrm{p}=0,528)$ dengan kejadian MCI. Dengan kesimpulan penelitiannya ini dapat disimpulkan bahwa kejadian MCI dapat dipengaruhi oleh masa kerja dan frekuensi penyemprotan. MCI atau Gangguan Kognitif Ringan merupakan kondisi gangguan kognitif obyektif dengan gejala klinis menuju terjadinya dimensia yang masih masuk kedalam gangguan neurobehavioral. 
3. Hubungan Gangguan Neurobehavioral Dengan Paparan Pestisida Pada Pekeja Perkebunan teh PT. X Kabupaten Cianjur

Hasil penelitian menunjukkan bahwa sebagian besar responden yang diteliti yaitu sebanyak 16 orang $(53,3 \%)$ mengalami paparan pestisida yang akut dan sebanyak 14 orang $(46,7 \%)$ mengalami paparan pestisida yang kronis.

Hasil penelitian yang lain yang menyebutkan faktor-faktor yang berhubungan dengan gejala neurotoksik akibat paparan pestisida pada petani sayur di kenagarian Alahan Panjang Kabupaten Solok dengan latar belakang, Sekitar 60\% petani penyemprot sayur di Kanagarian Alahan Panjang mempunyai riwayat gejala neurotoksik. Penelitian ini bertujuan untuk mengkaji faktor-faktor yang berhubungan dengan gejala gangguan syaraf pada petani penyemprot yang menggunakan pestisida di Kanagarian Alahan Panjang Kabupaten Solok. Metode penelitian ini merupakan penelitian observasional dengan rancangan cross-sectional. Subyek penelitian sebanyak 75 responden. Penarikan sampel dilakukan secara random. Variabel yang dikaji dalam penelitian ini meliputi jenis pestisida, komposisi pestisida, pemakaian alat pelindung diri, dan gejala neurotoksik. Instrument penelitian menggunakan kuesioner Q18 versi Jerman. Analisis data menggunakan uji Chi-square pada taraf signifikasi 5\%. Hasil penelitian menunjukkan sebanyak $62,7 \%$ petani penyemprot sayuran pernah mengalami gejala neurotoksik. Hasil analisis statistik menunjukan ada hubungan signifikan antar jumlah dan komposisi pestisida yang digunakan dengan gangguan neurotoksik pada petani sayur ( $p$-value $<0,050$. Sedang kebiasaan pemakaian alat pelindung diri tidak berpengaruh terhadap kejadian gangguan neurotoksik. ${ }^{32}$

Hasil penelitian ini sama dengan bahwa terdapat hubungan/korelasi yang signifikan antara gangguan neurobehavioral dengan paparan pestisida pada pekerja perkebunan teh PT. X Kabupaten Cianjur, dengan menggunakan analisis statistik menggunakan uji Chi-square diperoleh nilai $\mathrm{p}$ value $=0,011<\alpha(0,05)$. sehingga terdapat hubungan/korelasi yang signifikan antara gangguan neurobehavioral dengan paparan pestisida pada pekerja perkebunan teh.

Dengan jumlah responden 30 orang yang hasilnya sebanyak 18 orang $(60,0 \%)$ memiliki gangguan neurobehavioral yang negative dan sebanyak 12 orang $(40,0 \%)$ memiliki gangguan neurobehavioral yang positif. Dan lama paparan pestisida yang menunjukkan bahwa sebagian besar responden yang diteliti yaitu sebanyak 16 orang $(53,3 \%)$ mengalami paparan pestisida yang akut dan sebanyak 14 orang $(46,7 \%)$ mengalami paparan pestisida yang kronis. Hubungan Gangguan Neurobehavioral Dengan Paparan Pestisida Pada Pekeja Perkebunan teh PT. X Kabupaten Cianjur diperoleh nilai $\mathrm{p}$ value $=0,011<\alpha(0,05)$ yang berarti bahwa terdapat hubungan/korelasi yang signifikan antara gangguan neurobehavioral dengan paparan pestisida pada pekerja perkebunan teh PT. X Kabupaten Cianjur.

Penelitian ini menggunakan kuesioner german Q18 dengan terdapat 18 pertanyaan. Pertanyaan-pertanyaan merujuk pada gangguan kognitif. Misalnya ingatan (memori), konsentrasi dan suasana hati (mood). Dalam penelitian Ihrig et. al. (2001), menyimpulkan bahwa kuesioner Q18 versi Jerman adalah kuesioner penapisan yang sensitif dan reliabel untuk keluhan yang terkait pajanan pelarut, tetapi tidak cukup reliabel untuk diagnosis individual. Peneliti juga membedakan cutt off point kuesioner ini berdasarkan jenis kelamin baik laki-laki maupun wanita. Untuk laki-laki cutt off point pada lima atau lebih keluhan kuesioner Q18 versi Jerman, sedangkan untuk wanita cutt off point nya enam atau lebih keluhan sebagai titik awal untuk evaluasi awal.

Gangguan Neurobehavior didefenisikan sebagai perubahan yang merugikan atau gangguan secara fungsional pada saraf, baik sistem saraf pusat maupun sistem saraf tepi yang diakibatkan oleh paparan bahan kimia, agen fisik maupun biologis yang lebih 
dikenal dengan zat neurotoksik. Gangguan ini mengakibatkan perubahan pada memori, attention, mood, disorientasi, penyimpangan berfikir, serta perubahan somatik, sensorik, dan fungsi kognitif sebagai efek neurotoksik akibat penggunaan neurotoksikan.

\section{Kesimpulan}

Simpulan umum penelitian ini adalah jumlah pekerja yang memiliki gangguan neurobehavional pada pekerja perkebunan teh adalah sebanyak 18 orang $(60,0 \%)$ memiliki gangguan neurobehavioral yang negative dan sebanyak 12 orang $(40,0 \%)$ memiliki gangguan neurobehavioral yang positif. Paparan Pestisida Pada Pekerja Perkebunan menunjukkan bahwa sebagian besar responden yang diteliti yaitu sebanyak 16 orang $(53,3 \%)$ mengalami paparan pestisida yang akut dan sebanyak 14 orang $(46,7 \%)$ mengalami paparan pestisida yang kronis. Adanya hubungan antara gangguan neurobehavioral dengan paparan pestisida sebagai pekerja perkebunan diperoleh nilai $\mathrm{p}$ value $=0,011<\alpha(0,05)$ yang berarti bahwa terdapat hubungan/korelasi yang signifikan antara gangguan neurobehavioral dengan paparan pestisida pada pekerja perkebunan teh PT. X Kabupaten Cianjur.

\section{Acknowledge}

Ucapan terima kasih dan juga penghargaan peneliti sampaikan kepada Pimpinan Fakultas Kedokteran Universitas Islam dan semua pihak yang telah banyak membantu proses pengumpulan data dan dalam membantu dalam penyusunan artikel ini.

\section{Pertimbangan Masalah Etik}

Penelitian dilakukan setelah mendapatkan persetujuan etik dari Komite Etik Fakultas Kedokteran Universitas Islam Bandung (Unisba) yaitu Nomor: 093/KEPKUnisba/X/2020. Identitas responden dijaga kerahasiannya.

\section{Daftar Pustaka}

[1] Dhamayanti, Fitriani Antika Saftarina, Fitria. Efek Neurobehavioral akibat Paparan Kronik Organofosfat pada Petani . Jurnal Agromedia .Vol 05. 498-502. 2018

[2] Desnizar I. Faktor-faktor yang berhubungan dengan gejala neurotoksik pada petani penyemprot tanaman sayuran dengan pestisida di Kenagarian Alahan Panjang kabupaten Solok tahun 2016. JKLI. 2016;16(1):17-21. 2016

[3] Yuantari MGC, Widiarnako B, Sunoko HR. Tingkat Pengetahuan Petani dalam Menggunakan Pestisida ( Studi Kasus di Desa Curut Kecamatan Penawangan Kabupaten Grobogan ). Semin Nas Pengelolaan Sumberd Alam dan Lingkung 2013:142-148.2013

[4] Fadilah Z. Efek Neuro behavioral dan faktor determinannya pada petani penyemprot tanaman sayur dengan pestisida di desa perbawati kabupaten sukabumi. Skripsi UIN Syarif Hidayatullah Jakarta. 2013.

[5] Kamel F, Hoppin JA. Association of pesticide exposure with neurologic dysfunction and disease. Environ Health Perspect. 2004;112(9):950-958. doi:10.1289/ehp.7135.2004

[6] Kim JY, Park S jin, Kim SK, et al. Pesticide exposure and cognitive decline in a rural South Korean population. PLoS One.;14(3):1-12. doi:10.1371/journal.pone.0213738.2019

[7] Jett DA. Neurotoxic pesticides and neurologic effects. Neurol Clin. 2017;29(2011):667-77. 2017

[8] Zakiyah N, Setiani O, Dianti NA. Hubungan paparan pestisida dengan gangguan perkembangan anak usia3-5 tahun di desa Girirejo kecamatan Ngablak kabupaten Magelang. 2017;5(3):403-10.2017

[9] Ariani Sistem Neurobehavior.Yogyakarta : Salemba Medika. 2011 
[10] London, Cheryl Beseler, Maryse F. Bouchard, David C. Bellinger, Claudio ColosioPhilippe Grandjean, Raul Harari, Tahira Kootbodien, Hans Kromhout, Francesca Little, Tim Meijster, Angelo Moretto, Diane . Rohlman, and Lorann Stallones. Neurobehavioural and neurodevelopmental effects of pesticide exposures. NIH Public Access Author Manuscript Neurotoxicology. Author manuscript; available in PMC 2013

[11] Baldi, Anne Gruber, Virginie Rondeau,Pierre Lebailly,Patrick Brochard, Colette Fabrigoule. Neurobehavioral effects of long-term exposure to pesticides: results from the 4-year follow-up of the PHYTONER Study. Occup Environ Med 2011;68:108e115. doi:10.1136/oem.2010.047811

[12] Gilden RC, Huffling K, Sattler B. Pesticides and health risks. J Obstet Gynecol Neonatal Nurs. 2010;39(1):103-10.

[13] Florian C, Farcas A, Matei AV, Coman G. Neurodevelopmental and Neurobehavioral Effects of Organophosphate Pesticides Exposure in Newborns and Children. NATO Sci Peace Secur Ser C Environ Secur. 2013;134:139- 45

[14] Rosas LG, Eskenazi B. Pesticides and child neurodevelopment. Curr Opin Pediatr. 2008;20:191-7.

[15] Costa LG, Giordano G, Guizzetti M, Vitalone A. Neurotoxicity of pesticides: a brief review. Front Biosci. 2008;13:1240- 9.

[16] Ameriana M. Perilaku petani sayuran dalam menggunakan pestisida kimia. JHort. 2008;18(1):95-106.

[17] Zakiyah N, Setiani O, Dewanti NAY. Hubungan paparan pestisida dengan gangguan perkembangan anak usia 3-5 tahun di Desa Girirejo Kecamatan Ngablak Kabupaten Magelang. Jurnal Kesehatan Masyarakat. 2017;5(3):402-10.

[18] Wismaningsih ER, Oktaviasari DI. Factors related the use of personal protective equipment (PPE) in farmers in Ngantru Tulungagung District. J Wiyata. 2015;2(2):102-7.

[19] Erwin I, Kusuma D. Inhibitor asetilkolinesterase untuk Menghilangkan Efek Relaksan Otot Non-depolarisasi. CDK. 2012;39(5):333-9.

[20] Wiadi IN, Muliarta IM. Fluktuasi tekanan darah dan efek performa neurobehavior pada paparan pestisida organofosfat jangka panjang pada remaja di daerah pertanian. E-Jurnal Med. 2017;6(4):63-72.

[21] Notoatmojo, Metodologi Penelitian Kesehatan. Edisi Revisi. Jakarta: Rineka Cipta.2012

[22] Riwidikdo, Handoko, Statistik Kesehatan.Yogyakarta. Mitra Cendikia Press.2012

[23] Lestari.Titik. Panduan Praktis Pengolahan data Komputer Dengan Aplikasi SPSS. Yogyakarta. Nuha Medika. 2019

[24] Sugiyono, Metodologi Penelitian Kuantitatif Kualitatif dan $R \& D$. Bandung ALFABETA.2017

[25] Ihrig, A., G. Triebig, dan M. C. Dietz. 2001. Evaluation of A Modified German Version of The Q16 Questionnaire for Neurotoxic Symptoms in Workers Exposed to Solvents. Occup Environ Med. 58:19-23

[26] Jurnal visikes, pengunaan pestisida sebagai faktor risiko "MCI" (Mild Cognitive Impairement) pada lansia di wilayah kerja puskesmas Mijen kota Semarang. Vol 13, No.1 April 2014.

[27] Introdustion to human physiology, Lauralee sherwood.2013

[28] WHO. 1986. Neurobehavioral Core Test Battery (NCTB). Operational Guide. Geneva: Oregon Health Sciences University.

[29] Dhamayanti FA, dan Saftarina F.2018.Efek Neurobehavioral akibat paparan Kronik Organofosfat pada petani.Vol 5,No 1 Juni 2018

[30] Putri N, Laksmidewi A.A, dan Adniana I.M.Paparan organofosfat kronik sebagai faktor resiko gangguan kognitif berdasarkan kadar phosphorylated tauserum.Neurona Vol 37,No 2 Maret 2020 
[31] Sari Devipurnama.2020.Hubungan antara paparan pestisida dengan kejadian mild cognitive impairement(MCI) pada petani di kecamatan sumowono kabupaten semarang. 